Sedimentary

Research
Journal of Sedimentary Research, 2022, v. 92, 1-11

Current Ripples

DOI: $10.2110 /$ jsr.2020.168
SEPM

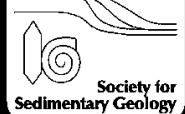

\title{
HOW DISTINCTIVE ARE FLOOD-TRIGGERED TURBIDITY CURRENTS?
}

\author{
CATHARINA J. HEEREMA, ${ }^{1}$ MATTHIEU J.B. CARTIGNY, ${ }^{1}$ RICARDO SILVA JACINTO, ${ }^{2}$ STEPHEN M. SIMMONS, ${ }^{3}$ RONAN APPRIOUAL, ${ }^{2}$ AND \\ PETER J. TALLING ${ }^{1}$ \\ ${ }^{1}$ Departments of Earth Science and Geography, Durham University, Lower Mountjoy, South Road, Durham DH1 3LE, U.K. \\ ${ }^{2}$ IFREMER, Géosciences Marines, Centre de Bretagne ZI Pointe du Diable, CS 10070, 29280 Plouzané, France \\ ${ }^{3}$ Energy and Environment Institute, University of Hull, Hull HU6 7RX, U.K.
}

\begin{abstract}
Turbidity currents triggered at river mouths form an important highway for sediment, organic carbon, and nutrients to the deep sea. Consequently, it has been proposed that the deposits of these flood-triggered turbidity currents provide important long-term records of past river floods, continental erosion, and climate. Various depositional models have been suggested to identify river-flood-triggered turbidite deposits, which are largely based on the assumption that a characteristic velocity structure of the flood-triggered turbidity current is preserved as a recognizable vertical grain size trend in their deposits. Four criteria have been proposed for the velocity structure of flood-triggered turbidity currents: prolonged flow duration; a gradual increase in velocity; cyclicity of velocity magnitude; and a low peak velocity. However, very few direct observations of flood-triggered turbidity currents exist to test these proposed velocity structures. Here we present direct measurements from the Var Canyon, offshore Nice in the Mediterranean Sea. An acoustic Doppler current profiler was located $6 \mathbf{k m}$ offshore from the river mouth, and provided detailed velocity measurements that can be directly linked to the state of the river. Another mooring, positioned $16 \mathrm{~km}$ offshore, showed how this velocity structure evolved down-canyon. Three turbidity currents were measured at these moorings, two of which are associated with river floods. The third event was not linked to a river flood and was most likely triggered by a seabed slope failure. The multi-pulsed and prolonged velocity structure of all three (flood- and landslide-triggered) events is similar at the first mooring, suggesting that it may not be diagnostic of flood triggering. Indeed, the event that was most likely triggered by a slope failure matched the four flood-triggered criteria best, as it had prolonged duration, cyclicity, low velocity, and a gradual onset. Hence, previously assumed velocity-structure criteria used to identify flood-triggered turbidity currents may be produced by other triggers. Next, this study shows how the proximal multi-pulsed velocity structure reorganizes down-canyon to produce a single velocity pulse. Such rapid-onset, single-pulse velocity structure has previously been linked to landslide-triggered events. Flows recorded in this study show amalgamation of multiple velocity pulses leading to shredding of the flood signal, so that the original initiation mechanism is no longer discernible at just $16 \mathbf{~ k m}$ from the river mouth. Recognizing flood-triggered turbidity currents and their deposits may thus be challenging, as similar velocity structures can be formed by different triggers, and this proximal velocity structure can rapidly be lost due to selforganization of the turbidity current.
\end{abstract}

\section{INTRODUCTION}

Rivers directly connected to submarine channels and canyons are highly efficient in transporting large amounts of sediment, organic carbon, and pollutants to the deep sea (Galy et al. 2007). Consequently, the deep-sea depositional records from what have been interpreted as flood-triggered turbidity currents have been used to reconstruct paleo-floods (e.g., St-Onge et al. 2004; Plink-Björklund and Steel 2004; see review by Zavala et al. (2011) and references therein) and their recurrence rates (Mulder et al. 2001; Nakajima 2006). Such paleo-flood reconstructions rely on the underpinning assumptions that river floods create turbidity currents with a distinct velocity structure, and that this distinct velocity structure is recorded in the turbidite deposits through unique vertical grain size variations (Kneller and McCaffrey 2003; Mulder et al. 2003). It is assumed that this vertical grain size trend translates to an identifiable velocity time series at a fixed point, from here on referred to as velocity structure. Proposed criteria to identify the velocity structure of a flood-triggered turbidity current include: 1) a prolonged duration due to the long time scale of river flooding in comparison to most slope failures (Mulder et al. 2003; Zavala and Pan 2018); 2) a gradual velocity increase at the start of the turbidity current (waxing) associated with the rising limb of the river discharge, followed by a waning turbidity current (Mulder et al. 2003); 3) multiple cycles of acceleration and deceleration (pulses) reflecting discharge fluctuations that are common in river floods (Khripounoff et al. 2012; Zavala and Pan 2018); and 4) a low peak velocity, as floodtriggered turbidity currents are expected to be dilute and thus slow in comparison to the much denser landslide-triggered flows (Mulder et al. 2003; Nakajima 2006; Khripounoff et al. 2012; Zavala and Pan 2018). These four criteria are important in paleo-flood reconstructions as they are 
used to distinguish between flood-triggered and landslide-triggered turbidity currents, with landslide-triggered flows characterized by a sudden onset with a high peak frontal velocity (Kirwan et al. 1986; Normark and Piper 1991; Kneller and Buckee 2000; Mulder et al. 2003). However, there are few field observations of velocity structures in turbidity currents measured offshore from river mouths to validate such an approach. To our knowledge, there are just five locations with direct measurements of such velocity structures (Khripounoff et al. 2009, 2012; Liu et al. 2012; Hughes Clarke 2016; Lintern et al. 2016; Azpiroz-Zabala et al. 2017; Hage et al. 2019; Simmons et al. 2020).

The velocity structures measured at these five locations of floodtriggered turbidity currents are not always consistent with the abovementioned criteria. For example, observations in the Var Canyon, in the Mediterranean Sea, have shown that landslide-triggered events can last twice as long as flood-triggered events (Khripounoff et al. 2012). Events in the Congo Canyon have been measured to last up to 10 days (Simmons et al. 2020), although the events in the Congo Canyon are typically associated with elevated river discharge, and not flood peaks (Bailey et al. 2021). A gradual increase in velocity was measured in a flood-triggered turbidity current in the Gaoping Canyon, offshore Taiwan (Liu et al. 2012), but not in the flood-triggered flows in the Var Canyon (Khripounoff et al. 2012), on the Fraser Delta, British Columbia (Lintern et al. 2016), or at the Squamish Delta, British Columbia (Hughes Clarke 2016; Hage et al. 2019). Although multiple cycles of acceleration and deceleration are observed in the Var Canyon (Khripounoff et al. 2012), they have not been observed in the other locations (Liu et al. 2012; Lintern et al. 2016; Hughes Clarke 2016; Hage et al. 2019). Finally, the Var Canyon observations show that flood-triggered flows are indeed somewhat slower than landslidetriggered flows (Khripounoff et al. 2012), but in the Gaoping Canyon the observations show opposite velocity trends, as turbidity currents linked to river floods are the fastest (Gavey et al. 2017). Moreover, the turbidity currents observed in some river-associated systems strongly resemble landslide-triggered flows with a single pulse characterized by a sudden onset (Hughes Clarke 2016; Lintern et al. 2016; Azpiroz-Zabala et al. 2017; Hage et al. 2019; Simmons et al. 2020). Overall, the variability in the direct observations show that using the velocity structure of a turbidity current to identify a flood trigger is problematic and more field measurements are needed to understand these variations.

Several mechanisms could explain the inconsistencies observed in the velocity structures of flood-triggered turbidity currents. For example, the duration of a turbidity current can change significantly down canyon due to stretching of the flow (Azpiroz-Zabala et al. 2017). Initially slow flows can accelerate rapidly as they start to bulk up due to erosion of the seafloor (Parker et al. 1986; Sequeiros et al. 2009; Hage et al. 2019; Heerema et al. 2020), and multiple velocity pulses in the same event can merge, i.e., amalgamate (Kneller and McCaffrey 2003; Ho et al. 2018). Additionally, the velocity structure of flood-triggered turbidity currents is likely to vary significantly depending on the exact process by which the sediment is transferred from the river to the turbidity current. Three such transfer mechanisms have been proposed for marine settings. First, at sufficiently high sediment concentrations $\left(36-43 \mathrm{~kg} \mathrm{~m}^{-3}\right)$, excess sediment density causes a river plume to be denser than seawater, leading to a hyperpycnal river that plunges and continues along the seabed as a turbidity current (Mulder and Syvitski 1995). Second, sea-surface (hypopycnal) river plumes can generate turbidity currents. Convective fingers of settling sediment can occur in such hypopycnal plumes at sediment concentrations of as little as $1 \mathrm{~kg} \mathrm{~m}^{-3}$ (Parsons et al. 2001). Third, substantially more dilute river plumes $\left(0.07 \mathrm{~kg} \mathrm{~m}^{-3}\right)$ have recently been found capable of initiating turbidity currents, by generating high sediment concentration due to near-bed flow convergence in tidal settings (Hage et al. 2019). The range of possibilities outlined above, combined with the scarcity of seafloor observations, severely limits paleo-flood reconstructions. High-resolution velocity measurements near the river mouth are needed to test the variability of turbidity currents close to the river mouth. Additionally, further velocity measurements down-canyon are needed to test how far down the system any potential flood-triggered velocity structure is preserved.

\section{AIMS}

Here we present new field measurements of three turbidity currents offshore from the Var River mouth. This study extends the earlier work of Khripounoff et al. (2009; 2012) in this system. In this new study, highresolution acoustic Doppler current profiler (ADCP) measurements of turbidity currents were collected just $6 \mathrm{~km}$ offshore from the river mouth. This ADCP mooring deployment is closer to the river mouth than used by Khripounoff et al. $(2009,2012)$, and allows us to monitor the proximal velocity structure of the Var Canyon turbidity currents in unprecedented detail. We use these measurements to test the link between river floods and velocity structure of the turbidity currents. More specifically, we test whether the previously proposed criteria indeed distinguish flood-triggered turbidity currents from other triggers, at locations close to the river mouth. We then use a second mooring farther offshore $(16 \mathrm{~km})$ to test whether such proximal velocity structure is preserved down-canyon. Finally, we discuss the implications of these findings for reconstructing paleo-flood records from turbidity-current deposits.

\section{TERMINOLOGY}

Confusion can occur if terms are not clearly defined, and terms such as "hyperpycnal" have been used by different authors in somewhat different ways (Shanmugam 2018; Feng 2019; Zavala 2019). We therefore specify the terminology used throughout this paper. We define a turbidity current as a gravity-driven subaqueous sediment density flow, where the dominant particle support is fluid turbulence (Mulder and Alexander 2001), although turbulence may be damped in near-bed layers that characterize high-density turbidity currents (Lowe 1982; Kneller and Branney 1995; Cantero et al. 2012; Eggenhuisen et al. 2017). We call a turbidity current "floodtriggered" if sediment suspended during a river flood (a distinct, sharp peak in river discharge) directly transfers into the turbidity current. Such direct transfer of flood-derived sediment could occur via two of the earliermentioned mechanisms; instantaneously via plunging (Mulder et al. 2003) or via concentrated pockets of sediment in convective fingers (Parsons et al. 2001). We reserve the term "hyperpycnal turbidity currents" for turbidity currents that are direct continuations of plunging rivers (Talling 2014). All non-flood-triggered turbidity currents occurring in a river-fed submarine channel are here labeled as "river-associated" turbidity currents and include flows triggered by tides (Hage et al. 2019) and submarine landslides (Hughes Clarke et al. 2014). More specifically, we use the term "landslide-triggered" for surge-like turbidity currents, commonly assumed to be of short duration due to non-permanent sediment supply (Mulder and Alexander 2001), and consisting of a sudden onset with high-velocity front and a subsequent waning flow (Kneller and Buckee 2000). The term "velocity structure" is used for a time series of velocity measured at a single spatial point (e.g., mooring). Merging of pulses (distinct velocity peaks) in the velocity time series is referred to as "amalgamation."

\section{STUDY AREA}

The Var Canyon is located offshore Nice in the Mediterranean Sea, and extends for approximately $20 \mathrm{~km}$ before joining with the Paillon Canyon at $1850 \mathrm{~m}$ water depth (Fig. 1A; Piper and Savoye 1993). The Var Canyon begins directly at the Var River mouth. The Var River discharge has a yearly cyclicity of enhanced discharge in the spring and summer due to snow melt, followed by high-intensity rainfall floods separated by low river 


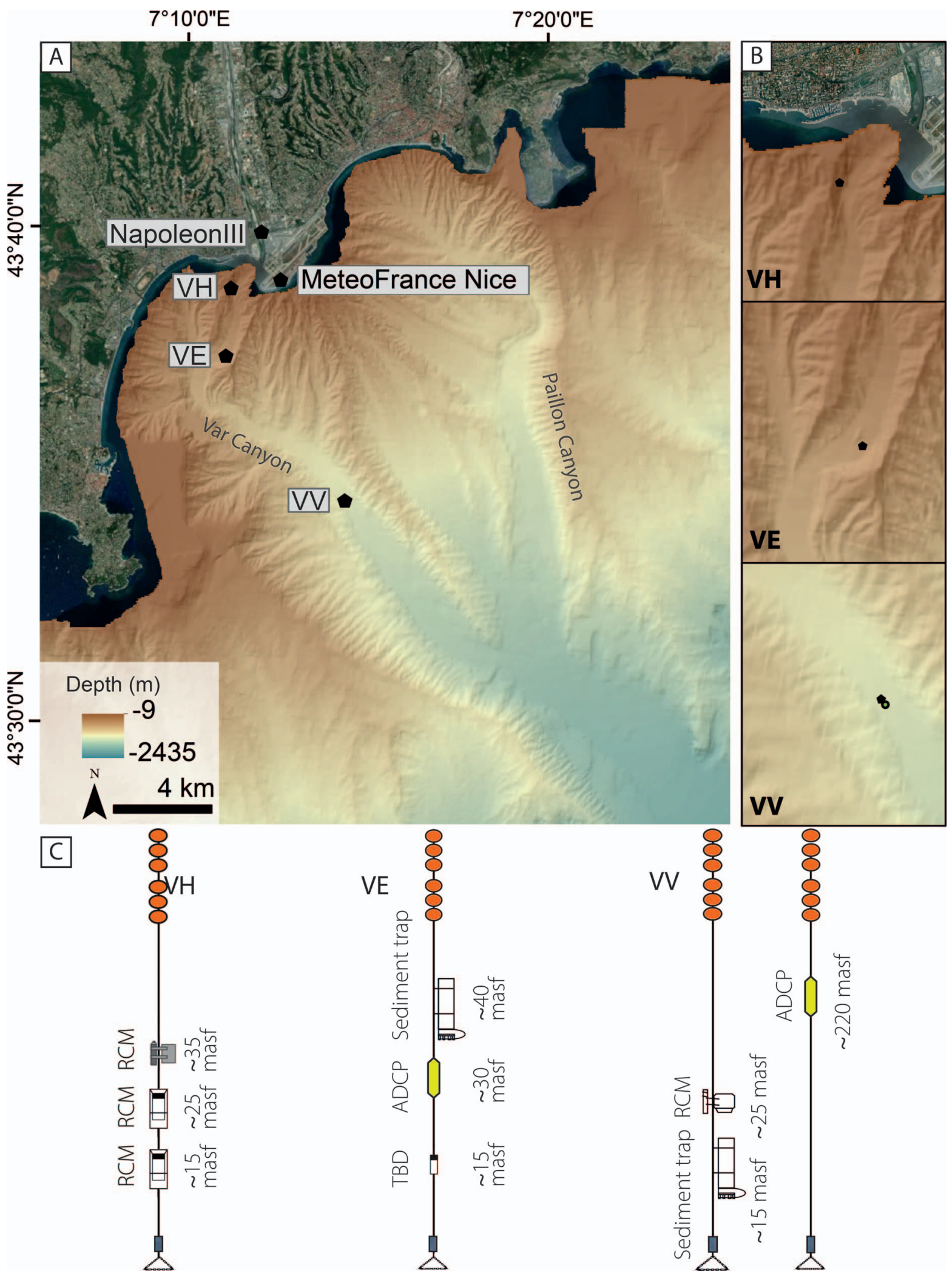

FIG. 1.-A) Overview map of Var Canyon showing locations of three mooring stations (VH, VE, and VV), and measurement stations for river discharge (Napoleon III) and meteorological data (MeteoFrance). B) Detailed bathymetric maps of each mooring station. Note that mooring VH is offset from the canyon axis, and mooring VV moved a small distance during flows. C) Set-up for each mooring, including both moorings at the VV site. ADCPs measure velocity profiles. RCMs are single-height current meters, and TBD is a turbidity sensor. Height in meters above seafloor (masf) are indicated. 
TABLE 1.-Overview of three main events measured at multiple sites (events 1, 4, and 5 in Fig. 3).

\begin{tabular}{|c|c|c|c|c|c|c|c|}
\hline & & \multicolumn{2}{|c|}{ July (Event 1) } & \multicolumn{2}{|c|}{ October (Event 4) } & \multicolumn{2}{|c|}{ December (Event 5)* } \\
\hline \multirow[t]{2}{*}{ Var River } & River Discharge $\left(\mathrm{m}^{3} / \mathrm{s}\right)$ & \multicolumn{2}{|c|}{80} & \multicolumn{2}{|c|}{250} & \multicolumn{2}{|c|}{765} \\
\hline & $\begin{array}{l}\text { Calculated Suspended } \\
\text { Sediment Concentration }\left(\mathrm{kg} / \mathrm{m}^{3}\right) \\
\text { (after Mulder et al. 1998) }\end{array}$ & & -3 & \multicolumn{2}{|c|}{$4-8$} & \multicolumn{2}{|c|}{$20-50$} \\
\hline \multirow[t]{8}{*}{ Var Canyon } & Station & VE & VV & VE & VV & VE & VV \\
\hline & Onset & Gradual & Sudden & Sudden & Sudden & Sudden & Sudden \\
\hline & Cycles of velocity & Multiple surges & 3 distinct repeats & Multiple surges & 1 acceleration & Multiple cycles & 1 acceleration \\
\hline & Peak velocity $(\mathrm{cm} / \mathrm{s})$ [transit velocity] & 34.8 & $26.4[6.9]$ & 61.8 & $30.2[75.8]$ & 101.6 & $84.4[64.1]$ \\
\hline & Flow duration (hrs) & $79-81 \mathrm{hrs}$ & $71-78 \mathrm{hrs}$ & $21-25 \mathrm{hrs}$ & $10-13 \mathrm{hrs}$ & $39-41 \mathrm{hrs}$ & $85-97 \mathrm{hrs}$ \\
\hline & Flow height (m) [approx] & $\sim 20 \mathrm{~m}$ & $150 \mathrm{~m}$ & $>30 \mathrm{~m}$ & $130 \mathrm{~m}$ & $>30 \mathrm{~m}$ & $150 \mathrm{~m}$ \\
\hline & Temperature rise ( ${ }^{\circ}$ Celsius) & 0 & 0.2 & 0 & 0.2 & 0.2 & 0.2 \\
\hline & Sediment flux (g/m $/ \mathrm{m}^{2}$ day) & 1624 & 242 & 532 & 90 & 5707 & 4956 \\
\hline
\end{tabular}

* Only second stage of December event, 25th December onwards

discharges during the winter (Mulder et al. 1998). The average annual discharge is $50 \mathrm{~m}^{3} \mathrm{~s}^{-1}$, with the biannual flood recurrence at $810 \mathrm{~m}^{3} \mathrm{~s}^{-1}$ (http://www.hydro.eaufrance.fr).

The Var Canyon turbidity-current activity is well known from the large landslide-triggered turbidity current that occurred during the construction of Nice Airport in 1979 (Mulder et al. 1997). Khripounoff et al. (2009, 2012) published the only studies in the Var Canyon that used direct velocity measurements of turbidity currents in this system. They found that in the canyon several turbidity currents are initiated each year either by river floods or submarine landslides (Khripounoff et al. 2012). Typical turbidity current velocities are from 20 to $90 \mathrm{~cm} \mathrm{~s}^{-1}$, with a duration between 4 and 24 hours, and a flow thickness between 50 and $130 \mathrm{~m}$ (Khripounoff et al. 2009, 2012). In the Var Canyon, flood-triggered turbidity currents are found to have the lowest velocities, shortest duration, and highest vertical extent (Table 1 in Khripounoff et al. 2012).

\section{METHODS}

Here we analyze a new dataset from the Var River-Canyon system that was collected during the Solveig III research cruise, acquired over a period of seven months, from late June 2009 to early February 2010 (Fig. 2; Blandin 2010). We first compare velocity data from a proximal canyon mooring to river discharge measurements, to analyze the relationship between the velocity structure of turbidity currents and associated river discharge. We then use a second mooring to trace the changes in the velocity structure of the turbidity currents down the canyon. Another, third mooring was located directly offshore the river mouth $(2.8 \mathrm{~km})$, but it unfortunately was located just outside the deepest part of the canyon floor (thalweg) and consequently did not record any turbidity currents.

\section{Land Stations}

Var River discharges were recorded at the Napoleon III site (Nice, France; Fig. 1A) every 15 minutes (HYDRO http://www.hydro.eaufrance. fr). Near Nice Airport, a MeteoFrance weather station recorded hourly maximum wind speeds based on 10-minute average values, as well as precipitation on an hourly basis (Fig. 2A).

\section{Var Canyon Mooring Configuration}

Initially three moorings (VH, VV, VE) were deployed in the Var Canyon (Fig. 1A, B). The shallowest mooring $(\mathrm{VH})$ was potentially located outside the deepest part of the canyon thalweg (Fig. 1B). It is especially challenging to deploy moorings precisely in the thalweg center in this narrow proximal part of the canyon. Consequently, the exact seabed location of mooring $\mathrm{VH}$ in relation to the channel thalweg remains uncertain, due to the potential offset between the release location of the mooring and its final landing location. This mooring did not measure any turbidity currents, but the mooring set-up and the resulting data are still presented briefly here to provide a complete overview of the observations. However, these observations are not analyzed in as much detail as those from the other moorings, which were located in the thalweg. Most instruments on the moorings recorded at a 20 -minute interval, unless stated otherwise.

Station VH was located on the side wall of the submarine canyon at 121 meters water depth (mwd), and $2.8 \mathrm{~km}$ from the Napoleon III measurement station at the river mouth (Fig. 1A, B). On this mooring, there was a Seaguard Recording Current Meter (RCM) at 15 meters above the seafloor (masf), an RCM 11 at 25 masf that recorded every 5 minutes, and an Aquadopp RCM at 35 masf recording at $30 \mathrm{~min}$ intervals (Fig. 1C).

Station VE was deployed at $518 \mathrm{mwd}$, at a location $5.7 \mathrm{~km}$ from Napoleon III (Fig. 1A, B). Mooring VE had a turbidity sensor mounted at 15 masf (Fig. 1C). A $300 \mathrm{kHz}$ acoustic Doppler current profiler (ADCP) was mounted at 30 masf, which recorded over a series of 2-m-high bins. Besides the maximum velocity, the velocity at 25 masf is also extracted from the ADCP data to enable a direct comparison between the depthresolved ADCP data and the single depth point RCM measurements on the other moorings. A sediment trap (PPS 4/3-Technicap) was mounted at 40 masf. Settling particles were collected over a 9-day window using cylindrical sediment traps with a sampling aperture of $0.05 \mathrm{~m}^{2}$. These traps were covered with a honeycomb baffle with 10 -cm-deep cells, which were $1 \mathrm{~cm}$ in diameter, and were equipped with 24 sampling bottles.

Station VV was located at $1280 \mathrm{mwd}, 15.7 \mathrm{~km}$ away from the river mouth (Fig. 1A, B). Here, the sediment trap was located at 15 masf (Fig. 1C), with the same specifications and set-up as at station VE. A RCM 11 was installed at 25 masf. An additional mooring with a $75 \mathrm{kHz}$ ADCP, at 220 masf, was deployed at the same location. The height of this mooring allows the calculation of flow thickness, using calculations of depthaveraged height following the integral definition of Stacey and Bowen (1988). This ADCP recorded every 5 minutes, and had a $6 \mathrm{~m}$ vertical bin size.

Sediment concentrations in the flows were also estimated using backscatter data of the $300 \mathrm{kHz}$ ADCP at station VE. This provides further information on first-order flow character, but involves a significant assumption that grain size does not vary with height above the bed (see Simmons et al. (2020) for a detailed description of likely errors associated with this assumption). However, it is established that grain size will increase towards the bed, with grain-size stratification depending on the Rouse number and other factors (e.g., Kneller and Buckee 2000; Eggenhuisen et al. 2020). Due to this simplification, the primary conclusions from this contribution are thus based only on ADCP velocity measurements, with the sediment concentrations contributing further 

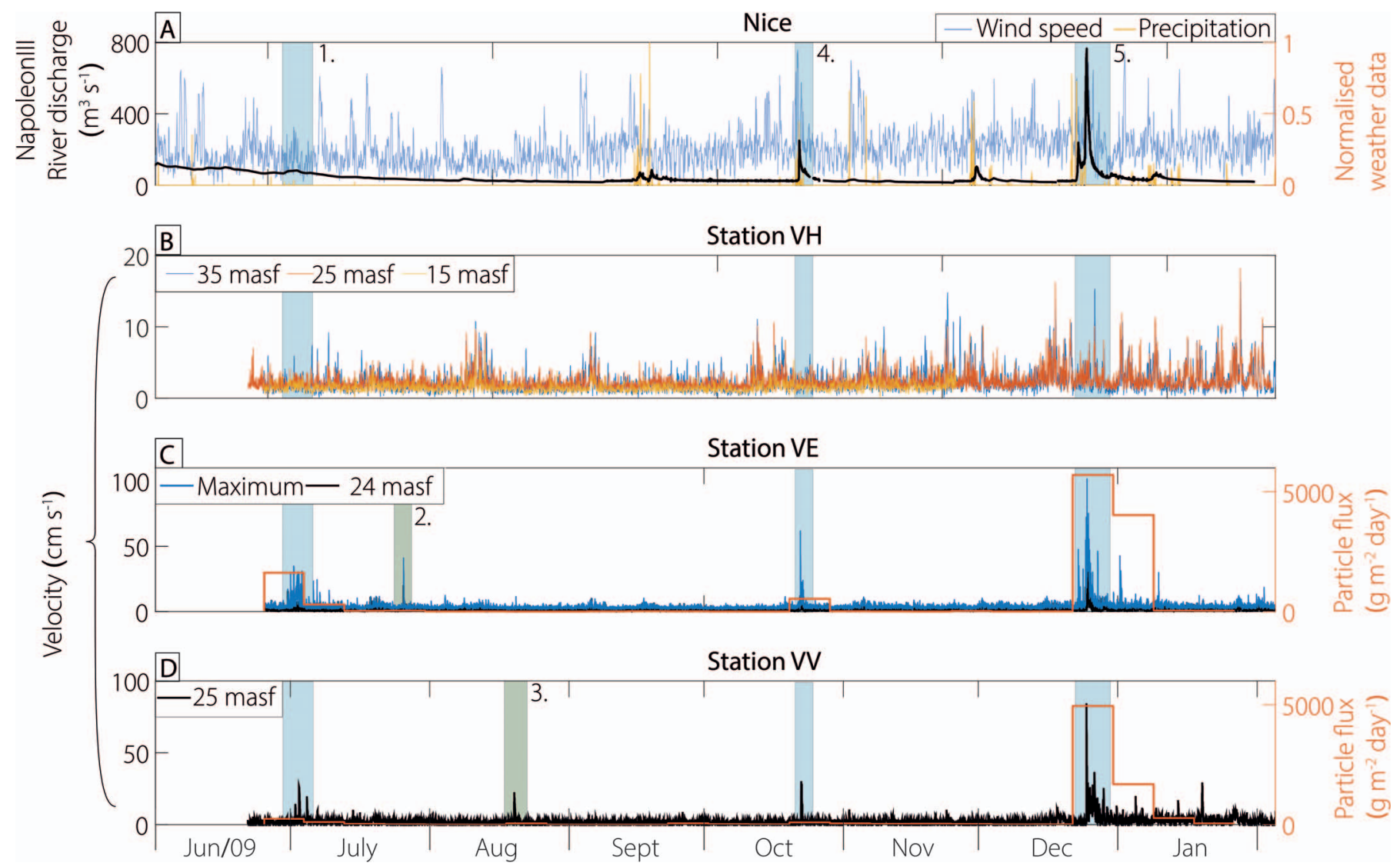

FIG. 2.-Complete time series of monitoring data. Five turbidity current events are highlighted, and numbered from 1 to 5 . The three flows recorded at all moorings are shown by blue boxes, whilst green boxes highlight events only recorded at individual stations. A) Detailed time series of data from land stations. The Napoleon III station provides river discharge data. Data on wind speed and precipitation come from the MeteoFrance station, and these weather data are normalized using the minimum and maximum values that occurred during the study period. B) Velocity measurements from single-height current meters (RCMs) at station VH, located at 15,25 , and 35 meters above seafloor (masf). C) Velocity measurements from a $300 \mathrm{kHz}$ ADCP at station VE. Maximum velocity, and velocity at 24 masf, are shown for comparison. Particle flux from a sediment trap at station VE, based on a nine-day average. D) RCM velocity measurement from station VV, located at 25 masf, and particle flux based on nine-day average.

information on flow properties. Briefly, the backscatter data were converted to sediment concentration using an implicit inversion method, with an iterative method of accounting for sediment attenuation (see Thorne and Hanes (2002) for a detailed description of the method). The intensity of the acoustic backscatter depends on both grain size of the suspended particles, as well as sediment concentration. When using a single-frequency ADCP, a vertical grain-size profile needs to be assumed for each measurement in the flow (Simmons et al. 2020). This grain size can be derived from sediment cores or traps (cf. Azpiroz-Zabala et al. 2017). Here, we assume a single grain-size value for all vertical profiles, as vertical grain-size stratification in the flow cannot be quantified on the basis of sediment-trap samples available here. The sediment-trap samples used for grain-size estimates came from the Solveig I cruise (Silva Jacinto 2008) between late November 2008 and early December 2008. The Solveig III sediment trap samples were used for destructive sampling of carbon, so they were unavailable for grain-size measurements. During the Solveig I cruise, a sediment trap was located near the river mouth, at $500 \mathrm{mwd}$, and it returned a mean grain size of $40 \mu \mathrm{m}$. Furthermore, estimates of sediment concentration presented here assume that the ADCP constant $\left(\mathrm{K}_{\mathrm{t}}\right)$ is 2.31 $\times 10^{7}$ (Simmons et al. 2020). The $75 \mathrm{kHz}$ ADCP data, near station VV, is not used for conversion of acoustic backscatter to sediment concentrations, as there was no $\left(\mathrm{K}_{\mathrm{t}}\right)$ calibration value available for an instrument with similar frequency.

\section{RESULTS}

\section{Var River Observations}

The river discharge followed its standard yearly cycle comprising a longduration snowmelt peak over the spring and summer, and high-intensity rainfall floods during winter (Fig. 2A). During the initial four months from July to September 2009, the river discharge gradually declined from $200 \mathrm{~m}^{3}$ $\mathrm{s}^{-1}$ to $80 \mathrm{~m}^{3} \mathrm{~s}^{-1}$. Four winter floods occurred during the deployment (Fig. 2A). Two of these river-mouth floods exceeded $200 \mathrm{~m}^{3} \mathrm{~s}^{-1}$, with a peak discharge of $250 \mathrm{~m}^{3} \mathrm{~s}^{-1}$ in October 2009, and a maximum peak discharge of $765 \mathrm{~m}^{3} \mathrm{~s}^{-1}$ that occurred on December 2009. These two floods also correspond to increases in offshore flow velocities in the Var Canyon, indicating that turbidity currents were initiated in the Canyon (Fig. 2; events no. 4 and 5). The other two peaks in river discharge occurred in September and November 2009, with significantly lower discharges $\left(86\right.$ and $105 \mathrm{~m}^{3}$ $\mathrm{s}^{-1}$ ), and did not produce turbidity currents at the seafloor moorings. Analysis of the local wind speed did not yield any correlation between the occurrence of turbidity currents and high wind speeds, although the October 2009 event was preceded by a storm day (Fig. 2A, blue line).

\section{Var Canyon Observations}

At the most proximal station $\mathrm{VH}$, there was a notable lack of observable turbidity-current activity, with velocities limited to $20 \mathrm{~cm} \mathrm{~s}^{-1}$ (Fig. 2B). It is 

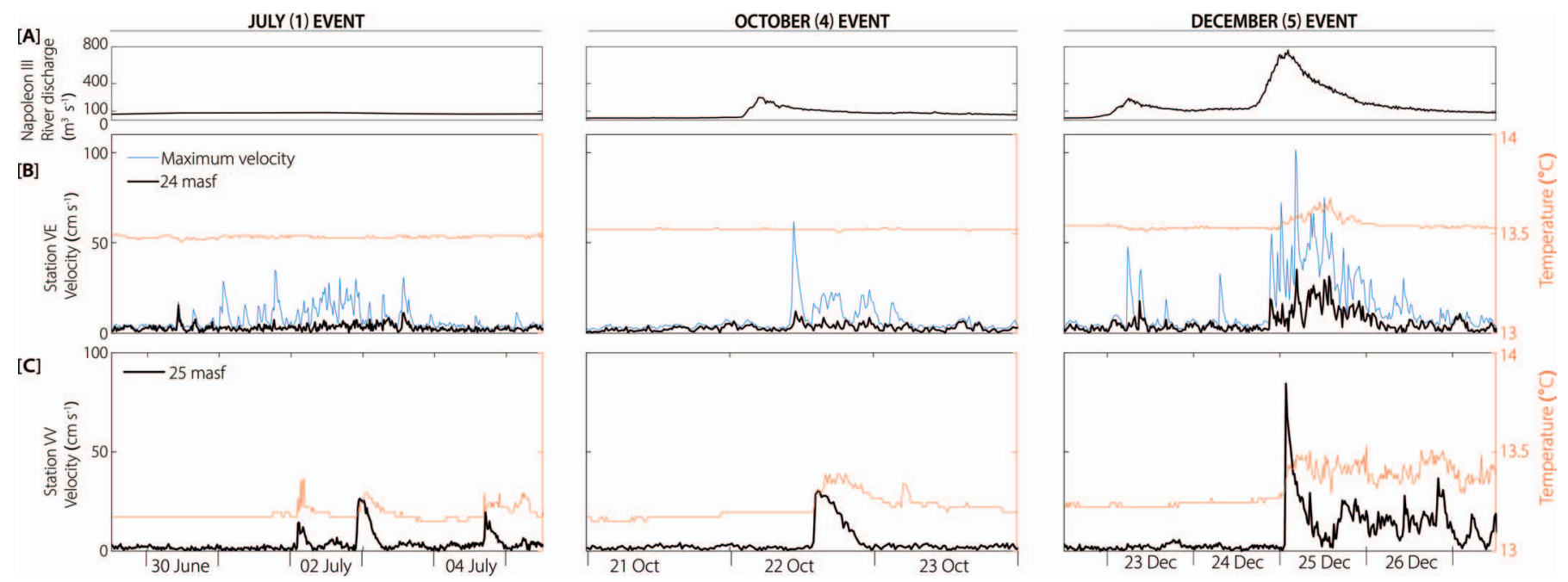

FIG. 3.-Detailed measurements for turbidity current events 1, 4, and 5 (see Fig. 2 for full time series). A) River discharge at the NapeoleonIII station. B) ADCP velocity (maximum recorded and at 25 masf) and temperature data from station VE. C) RCM velocity and temperature data (both at 25 masf) at station VV. The scale is the same for data on velocity and temperature at each station in Parts B and C.

most likely that the flows were not recorded at station VH because of its misplacement (Fig. 1B). Alternatively, either the proximal turbidity currents were not thick enough to reach the current meters placed at 15 masf, or the sediment plume from the river bypassed this VH mooring and flows started farther down-canyon. Given the off-center release location, the narrow V-shaped canyon shape, and the total lack of velocity, temperature, and turbidity signals, it is most likely that the mooring was misplaced.

Station VE (ADCP data) and VV (RCM current meter data) recorded five separate turbidity currents, which are termed flows $1,2,3,4$, and 5 (Fig. 2). Flows 2 and 3 were recorded only at a single mooring, and are considered to be minor local events, as neither flow led to increased sediment flux in traps (Fig. 2C, D). The three remaining events (flows 1, 4, and 5) did lead to an increased sediment flux, and were recorded by both mooring station VE and VV (Fig. 2; Table 1). These three flows are now discussed in more detail (Figs. 3, 4).

July 2009 Event (Event 1). - This turbidity current lasted from 30 June to 5 July 2009. During this period, the Var River lacked a distinct flood peak (Fig. 3A). Instead, the river's discharge $\left(\sim 80 \mathrm{~m}^{3} \mathrm{~s}^{-1}\right)$ continued a gradual decline following the peak snow melt in early spring (Fig. 2). Previous measurements have shown that comparable discharge levels in the Var River correspond to suspended-sediment concentration of up to $3 \mathrm{~kg}$ $\mathrm{m}^{-3}$ based on previous direct river measurements (Mulder et al. 1998).

At station VE, the July turbidity current lasted for nearly 3.5 days (Table 1). The velocity signal, as well as the sediment concentration, were characterized by a gradual onset followed by a long continuous series of pulses (Figs. 3, 4). Velocities and sediment concentrations gradually rose until a peak velocity of $35 \mathrm{~cm} \mathrm{~s}^{-1}$ occurred after roughly 1.3 days. Event 1 was not associated with an increase in temperature at station VE (Fig. 3B).

Ten kilometers farther down canyon, at station VV, the July event reorganized in three distinct pulses, each lasting for $\sim 5-10 \mathrm{hrs}$. All these pulses show a sharp increase in velocity and temperature at the start of the flow followed by a gradual decline (Fig. 3C). The peak velocities are similar to those measured in the proximal station (Table 1, Fig. 3). The transit velocity between station VE and $\mathrm{VV}$ is particularly slow at $\sim 7 \mathrm{~cm}$ $\mathrm{s}^{-1}$, suggesting that the first velocity peaks observed in VE dissipated before reaching station VV. The transit velocity would be more in agreement with the direct velocity measurements if a later velocity peak from station $\mathrm{VE}$ is considered to arrive first at station $\mathrm{VV}$, and earlier peaks dissipated between VE and VV.

October 2009 Event (Event 4).-Flow 4 in October 2009 coincided with a Var River flood with a discharge peak of $250 \mathrm{~m}^{3} \mathrm{~s}^{-1}$ (Fig. 3A), equating to a suspended sediment concentration in the river of $\sim 8 \mathrm{~kg} \mathrm{~m}^{-3}$ based on the Var River rating coefficient (Mulder et al. 1998). At station VE, the duration of the event was between 20 and 24 hours (Table 1). The velocity structure and sediment concentration consist of a sudden onset followed by a complex series of higher and lower pulses (Figs. 3B, 4B). A peak velocity of $62 \mathrm{~cm} \mathrm{~s}^{-1}$ occurs at the front of the turbidity current.

At station VV, the flow duration was reduced by $50 \%$ to $10-13$ hours (Figs. 3C, 4C, Table 1). The turbidity current is characterized by a single pulse with an abrupt onset. The velocity peaks at $30 \mathrm{~cm} \mathrm{~s}^{-1}$ at the start of the event, followed by a steady decline in velocity. Again, the increase in velocity at station $\mathrm{VV}$ is paired with an increase in temperature (Table 1, Fig. 3). The transit velocity between these two moorings, at $76 \mathrm{~cm} \mathrm{~s}^{-1}$, indicates an acceleration of the turbidity current before its arrival at station VV.

December 2009 Event (Event 5). - Event 5 is associated with the largest flood observed during this seven-month deployment (Fig. 2). This flood consisted of two stages, and occurred between 23 and 26 December. In the first stage (23rd December), the river discharge increases over an $\sim$ seven-hour window up to a peak discharge of $\sim 240 \mathrm{~m}^{3} \mathrm{~s}^{-1}$ (Fig. 3A). This first peak is followed by a 28 -hour period in which an elevated river discharge of $\sim 120 \mathrm{~m}^{3} \mathrm{~s}^{-1}$ was maintained. In the second stage (25th December), the flood reached its maximum discharge of $\sim 765 \mathrm{~m}^{3} \mathrm{~s}^{-1}$ in 10 hours (Fig. 3A). Overall, the second-stage flood lasted for about 39 hours, and the entire duration of elevated discharge during the December event was $\sim 3.5$ days. Estimation of the suspended-sediment concentration by extrapolating the rating curve of the river indicate that sediment concentrations of $20-50 \mathrm{~kg} \mathrm{~m}^{-3}$ are likely to have occurred during the second stage of the flood. Such levels of suspended sediment could be sufficient for the formation of a hyperpycnal turbidity current (Mulder et al. 1998).

At station VE, the measured velocities of the December event mirror the two-stage river discharge curve. On the 23rd of December, following the first stage of the river flood, a sharp increase in the velocity and sediment 


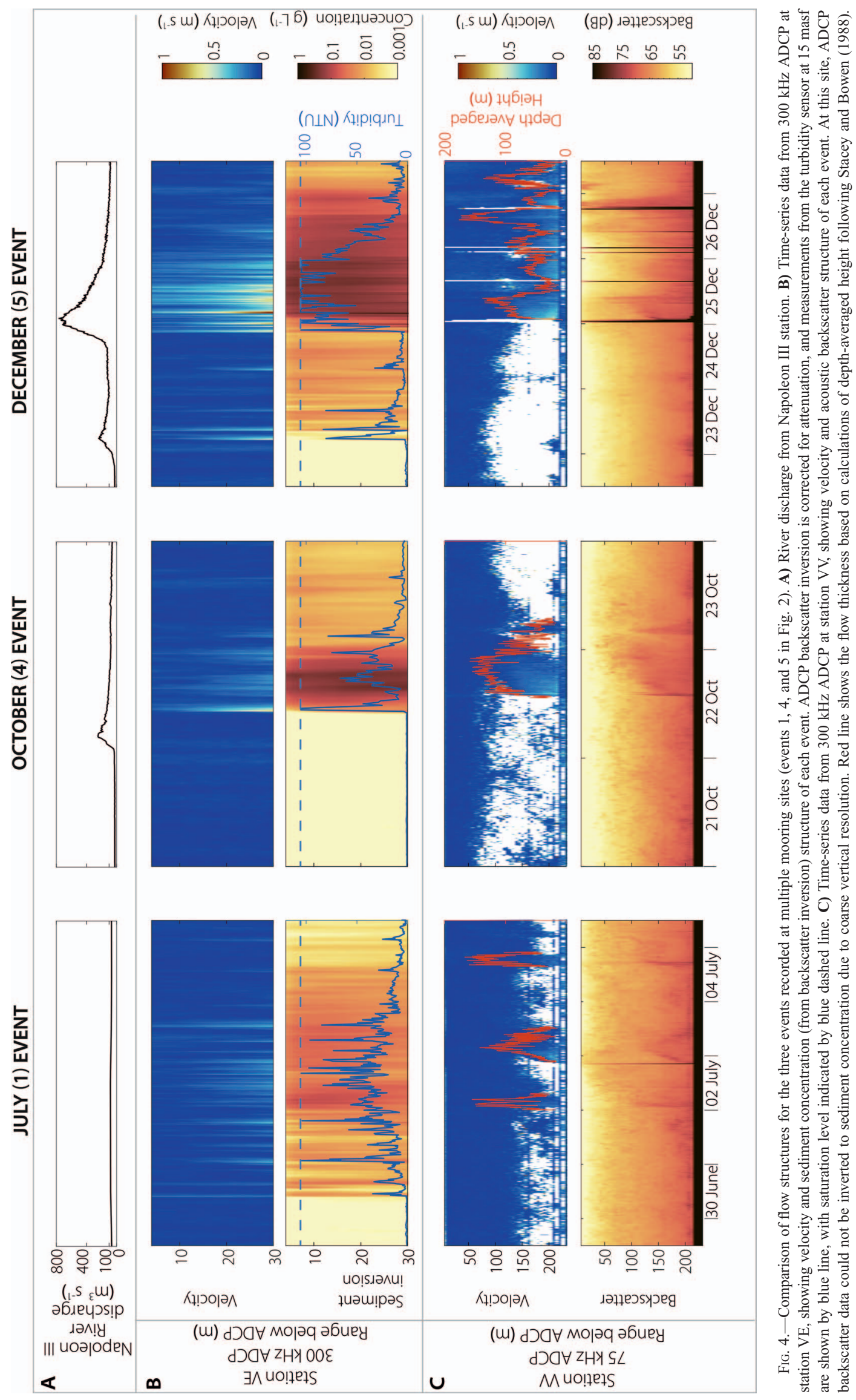


concentration is observed at VE (Figs. 3B, 4B). The sharp increase is followed by several lower velocity peaks until the second stage. As the river reaches its maximum discharge on the 25th of December, a series of new and higher velocity peaks are recorded at station VE. This second stage lasts for about 42 hours, has a sharp onset, with a further increase in sediment concentration, and reaches its peak velocity $\left(102 \mathrm{~cm} \mathrm{~s}^{-1}\right)$ about 7 hours after the start of this second stage (Figs. 3B, 4B; Table 1). Interestingly, the second stage of the December event is the only event that is significantly warmer than the ambient water at station VE.

The velocity peaks of the first stage of the December event are not observed at station VV. The arrival of the second stage is marked by a sharp increase in the velocity to its peak value of $85 \mathrm{~cm} \mathrm{~s}^{-1}$, which is followed by a continuous decrease lasting about 13 hours. In the following 3-4 days, multiple re-surging phases occur (Figs. 3C, 4C).

The transit velocity between station VE and VV, based on the first arrival time at either station, is $65 \mathrm{~cm} \mathrm{~s}^{-1}$. The observed maximum velocity peak at station VE $\left(102 \mathrm{~cm} \mathrm{~s}^{-1}\right)$ occurs after the arrival of the front peak at the more distal station $\mathrm{VV}$, and hence this proximal maximum velocity peak cannot be the distal maximal velocity peak. This observation implies that the maximum velocity peak at $\mathrm{VE}$ is not maintained down-canyon, but instead this proximal maximum velocity peak dissipates and becomes just a minor velocity peak at station VV.

\section{DISCUSSION}

\section{Is There a Unique Proximal Structure of Flood-Triggered Turbidity Currents?}

Four criteria have been proposed as diagnostic features of floodtriggered turbidity currents. These include a long duration, gradual onset, possible multiple cycles, and relatively low velocities (Khripounoff et al 2012; Zavala and Pan 2018; Mulder et al. 2003). All turbidity currents observed in the proximal station in the Var Canyon display at least two of these characteristics, as all events $(1,4,5)$ consist of multiple cycles and have a long duration in comparison to previous measurements in the Var Canyon (Khripounoff et al. 2012). The July event (event 1) was the only turbidity current with a gradual onset, and had low velocities in comparison to both the October and December events (events 4 and 5) as well as compared to events reported by Khripounoff et al. (2012). Thus, all three measured events at the proximal mooring show reasonable agreement with the four criteria set out for flood-triggered turbidity currents. Importantly, the July event does not coincide with a river flood, although the other two events are linked to floods (Fig. 3).

Although the July event (event 1) fits the flood-triggered criteria best, it lacks any association with a flood (Fig. 3A). However, during the October and December events the river floods produced sufficiently high suspended-sediment concentrations $\left(4-8 \mathrm{~kg} \mathrm{~m}^{-3}\right.$ for October and $20-50$ $\mathrm{kg} \mathrm{m}^{-3}$ for December; Table 1) to enable direct transfer of suspended sediment from the river to the turbidity current. For both October and December events, the sediment transfer could have occurred through convective fingering (Parsons et al. 2001). Additionally, the second stage of the December event (event 5) could be a hyperpycnal turbidity current, as the sediment concentration is sufficient for the river discharge to plunge and move along the seabed. Such a hyperpycnal trigger would be consistent with the unique increase in temperature observed at VE during this second stage.

The July event lacks a clear river flood (event 1, Figs. 2, 3). Yet, during the July event the suspended-sediment levels in the river discharge are estimated to be up to $3 \mathrm{~kg} \mathrm{~m}^{-3}$ (Table 1), which is still sufficient to form convective fingers (Mulder et al. 1998; Parsons et al. 2001). However, the river discharge measurements indicate that similar or higher levels of sediment concentration are expected continuously in the weeks leading up to the July event (Fig. 3A). Thus, if convective fingers were responsible for the transfer of sediment from the river to the submarine canyon, this should have resulted in continuous turbidity-current activity over the weeks leading up to the event. Such continuous turbidity-current activity was observed neither in the weeks leading up to the July event, nor in earlier measurements of Khripounoff et al. (2009) during similar conditions in the years 2006 and 2007. It is more likely that the July event was initiated by some form of landslide, which generated a relatively sustained flow at the proximal VE station (Fig. 3B). One possible hypothesis is that this turbidity current was triggered by retrogressive breaching failure, which can lead to continuous sediment supply and thus prolonged flow (Mastbergen and Van Den Berg 2003). The July event fits the floodtriggered criteria best (gradual onset, multiple cycles, low velocity, and long duration). Thus, it is important that this July event was most likely triggered by a landslide. Although the flood-triggered criteria are present in the Var Canyon observations, these criteria might not be unique to flood triggers.

\section{How Does the Proximal Velocity Structure Evolve Down-Canyon?}

We now discuss how the proximal velocity structure of the flows evolved and changed with distance, what controls the evolution of this velocity structure, and its implications for inferring triggers from grain-size patterns in deposits.

The typical proximal velocity structure observed in station VE is different from the typical velocity structure seen $10 \mathrm{~km}$ farther down canyon. At the proximal VE station, the three main events $(1,4,5)$ all show multiple cycles of acceleration and deceleration (pulses). However, at the $10 \mathrm{~km}$ more distal VV station, these multi-pulsed turbidity currents have self-organized to distinct single velocity peaks. For the October and December events, the flow reorganized to one distinct pulse, whilst the July event shows three distinct velocity peaks. These reorganized flow structures at the most distal VV station all show a dominant velocity peak at the front of the flow, followed by a steady decline; as typically expected for landslide-triggered turbidity currents (Kirwan et al. 1986; Normark and Piper 1991; Kneller and Buckee 2000; Mulder et al. 2003). This down-canyon transformation, from multi-pulsed to single-pulsed turbidity current, is consistent with field observations of Kneller and McCaffrey (2003) and laboratory experiments of Ho et al. (2018). Kneller and McCaffrey (2003) suggest that merging of velocity pulses can lead to simplified normally graded deposits towards the end of a canyon or channel system. Ho et al. (2018) also found that amalgamation of multipulsed flows is likely, as faster pulses within the flow experience a reduction in drag and consequently experience a forward advection to the flow front. The reduced drag is caused by the stratified water column that remained after the passage of the first pulse (Ho et al. 2018). The results shown here suggest that this amalgamation of pulses in the Var Canyon system is extremely efficient, leading to flooding signals effectively shredded within the first $16 \mathrm{~km}$ of the submarine canyon system.

However, the field observations also show that amalgamation of pulses is not as straightforward as seen in laboratory experiments. For example, during the second stage of the December event (25th of December onwards), the fastest peak is unable to catch up with the slower leading peak. Although this originally higher-velocity peak from station VE is discernible $10 \mathrm{~km}$ downstream, it is now slower than the frontal peak. This suggests that amalgamation of individual flow pulses also depends on other factors besides reduced drag. We propose that the pulse propagation also depends on availability of easily erodible substrate on the seafloor. For the second stage of the December event, the frontal pulse might have eroded the sediment freshly deposited by the first stage, causing the observed self-acceleration. Subsequently, the depleted seafloor could not fuel the following higher velocity peaks, resulting in deceleration of those initially higher velocity peaks. The importance of erosion and the state of the seafloor is consistent with previous observations. For example, Liu et 
al. (2012) documented that the first typhoon of the season produces the strongest turbidity current, Hage et al. (2019) showed that the first low tide of the spring cycle produces a fast and erosive turbidity current, and Heerema et al. (2020) showed that the first event after a prolonged quiescent period triggers the most ignitive flow. Overall, here in the Var Canyon the combined effect of erosion and amalgamation results in shredding of the flood signal within $16 \mathrm{~km}$ of the river mouth.

\section{Further Implications for Identifying Turbidity Currents Triggered by River Floods}

The Applicability of Depositional Models.-We now use our direct measurements to assess existing depositional models for flood-triggered events. The processes underpinning these models have been heavily debated (e.g., Shanmugam 2018; van Loon et al. 2019; Zavala 2019), and have led to three competing depositional models (Mulder et al. 2003; Plink-Björklund and Steel 2004; Nakajima 2006; Talling 2014). Central to the initial model from Mulder et al. (2003) is that waxing and waning of the river flood causes a waxing and waning turbidity-current velocity structure, and this is subsequently recorded in deposits via inverse-tonormal grading. This model suggests that the gradual rising limb of the river leads to a gradual increase in the velocity of the turbidity current, which in turn is recorded as a coarsening-upward (inversely graded) sequence in the deposits. Next, the falling limb of the flood produces a gradual decrease of the turbidity-current velocity that produces an upwardfining (normally graded) deposit. Later models of Plink-Björklund and Steel (2004) and Zavala et al. (2006) include incremental deposition of thick sandy deposits due to prolonged duration of hyperpycnal events. This in contrast to a third model that suggests that flood-triggered turbidity currents form thin, fine-grained deposits, due to the slow and dilute nature of flood-triggered turbidity currents (Nakajima 2006; Talling 2014).

In our direct measurements, we do indeed find prolonged durations of flood-triggered events 4 and 5. These events last up to four days, and could lead to thick deposits as suggested by Plink-Björklund and Steel (2004) and Zavala et al. (2006). The variable peak velocities $\left(26-102 \mathrm{~cm} \mathrm{~s}^{-1}\right)$ between the measured events could be consistent with both the proposed sandy beds (Plink-Björklund and Steel 2004; Zavala et al. 2006), as well as finer silt beds (Nakajima 2006; Talling 2014). However, the velocity onset of the events tends to be abrupt, especially at the distal station, suggesting that the inverse grading proposed by Mulder et al. (2003) becomes less likely with distance from the river mouth.

Notably, multiple inversely graded deposits are found on a terrace in the Var Canyon at $\sim 30 \mathrm{~km}$ from the Var River mouth, and are interpreted to reflect river-triggered turbidity currents (Mulder et al. 2001). These findings conflict with our measurements that demonstrate efficient selforganization of turbidity currents within $16 \mathrm{~km}$ from the Var River mouth. The existence of these inversely graded deposits of Mulder et al. (2001) suggest that some events retain their gradual velocity onset farther downcanyon, leading to these distal inversely graded deposits. Such flows are assumed to have lasted longer, reaching their peak velocity later, and hence would have required more time to self-organize; they may represent larger floods that are more prolonged. Therefore, these events would carry the waxing signal over greater distances, to form distal inversely graded deposits. Such events may be relatively infrequent, at least compared to the flow types measured in this study. The persistence of these inversely graded deposits farther offshore suggests that the recent direct monitoring observations do not yet include lower-frequency turbidity currents (Mas et al. 2010)

Some insights into the dynamics of such possible high-magnitude flows might be gained from the large hyperpycnal turbidity current in December. Proximally, this event does indeed have a gradual onset, as peak velocity occurs $\sim 7$ hours after the start of the event. However, amalgamation prevents the preservation of this gradual onset farther downstream.
Interestingly, the large hyperpycnal event (maximum river discharge 610 $\mathrm{m}^{3} \mathrm{~s}^{-1}$ ) measured by Khripounoff et al. (2012) on December 15, 2008 , shows that amalgamation is not always able to completely reorganize turbidity currents within the first $16 \mathrm{~km}$. The December 2008 event of Khripounoff et al. (2012) shows how a large flood-triggered flow generally resembles a landslide-triggered flow in terms of its velocity structure at location VV, just like the events presented here. However, this December 2008 event still consists of two distinct peaks at station VV (Khripounoff et al. 2012). The second, faster, peak is projected to catch up within $5-10 \mathrm{~km}$ to finalize self-organization into a single-peak, surge-type flow, based on their peak velocity and arrival times. Potentially, the incomplete amalgamation observed by Khripounoff et al. (2012) could be due to the fact that the rising limb of that December 2008 event lasted twice as long as the December 2009 flood presented here. It may thus be possible that during even longer river floods, the flood-triggered velocity structure is preserved farther offshore, thereby explaining the inversely graded deposits observed by Mulder et al. (2001).

In summary, all three depositional models are to some extent consistent with our direct measurement observations of flood-triggered events. Floodtriggered events could indeed result in sustained flows, indicated by traction structures, such as climbing ripples or plane-parallel lamination (Plink-Björklund and Steel 2004; Zavala et al. 2006). Especially proximally, large flood-triggered events could also result in inversely-tonormally graded sequences (Mulder et al. 2003), and vertical alternation of traction structures reflecting cyclicity in the flow (Nakajima 2006; Zavala et al. 2006). Although all proposed models work for some flows, it should be kept in mind that none of these depositional models apply exclusively to all flood-triggered flows. Furthermore, events without a flood trigger can also (partially) fulfill the proposed criteria for flood-triggered events. Finally, as previously suggested by Kneller and McCaffrey (2003), vertical-grading patterns in deposits are expected to simplify with distance from source, due to amalgamation of the velocity pulses over distance. This merging of velocity pulses leads to a simplified normal grading in distal positions. In this study, we show that this simplification can occur rapidly, within $16 \mathrm{~km}$ from the river mouth.

How Reliable Is the Depositional Record for Reconstructing PaleoFloods?-Turbidite records of paleo-floods have been used to reconstruct recurrence levels of river flooding (Mulder et al. 2001; Nakajima 2006), and to understand the effects of sea-level change on river floods (PlinkBjörklund and Steel 2004). However, this study has shown that although the velocity structure of flood-triggered turbidity currents is consistent with the proposed criteria, this structure is not unique to flood-triggered events (Fig. 5). For instance, initially multi-pulsed and prolonged velocity structures have been observed without a flood, as in the landslide-triggered July event (event 1). Moreover, similar river discharge levels have not consistently led to turbidity currents in the canyon. For example, Khripounoff et al. (2012) observed a $640 \mathrm{~m}^{3} \mathrm{~s}^{-1}$ river flood that did not immediately lead to a turbidity current, whilst a $610 \mathrm{~m}^{3} \mathrm{~s}^{-1}$ river flood did directly produce a turbidity current. Additionally, three similar river floods of $\sim 250 \mathrm{~m}^{3} \mathrm{~s}^{-1}$ led to substantially different turbidity current activity. A first flood $\left(230 \mathrm{~m}^{3} \mathrm{~s}^{-1}\right)$ described in Khripounoff et al. (2012) did not lead to any activity. A second flood $\left(240 \mathrm{~m}^{3} \mathrm{~s}^{-1}\right)$ during the first phase of the December event (described here) led to activity only at the first mooring. Lastly, the October flood $\left(250 \mathrm{~m}^{3} \mathrm{~s}^{-1}\right.$, described here) triggered an event that was observed at all mooring stations. Thus, recognition of paleo-floods based only on velocity structure and subsequent grain size trends might be problematic. Additional indicators, such as substantial organic-matter content with high carbon-nitrogen ratio, could be needed to confidently infer flood triggers. However, this may also be problematic, as seabed failures on the delta may also remobilize recently deposited sediment with similarly high organic-carbon contents or carbon-nitrogen rations. 


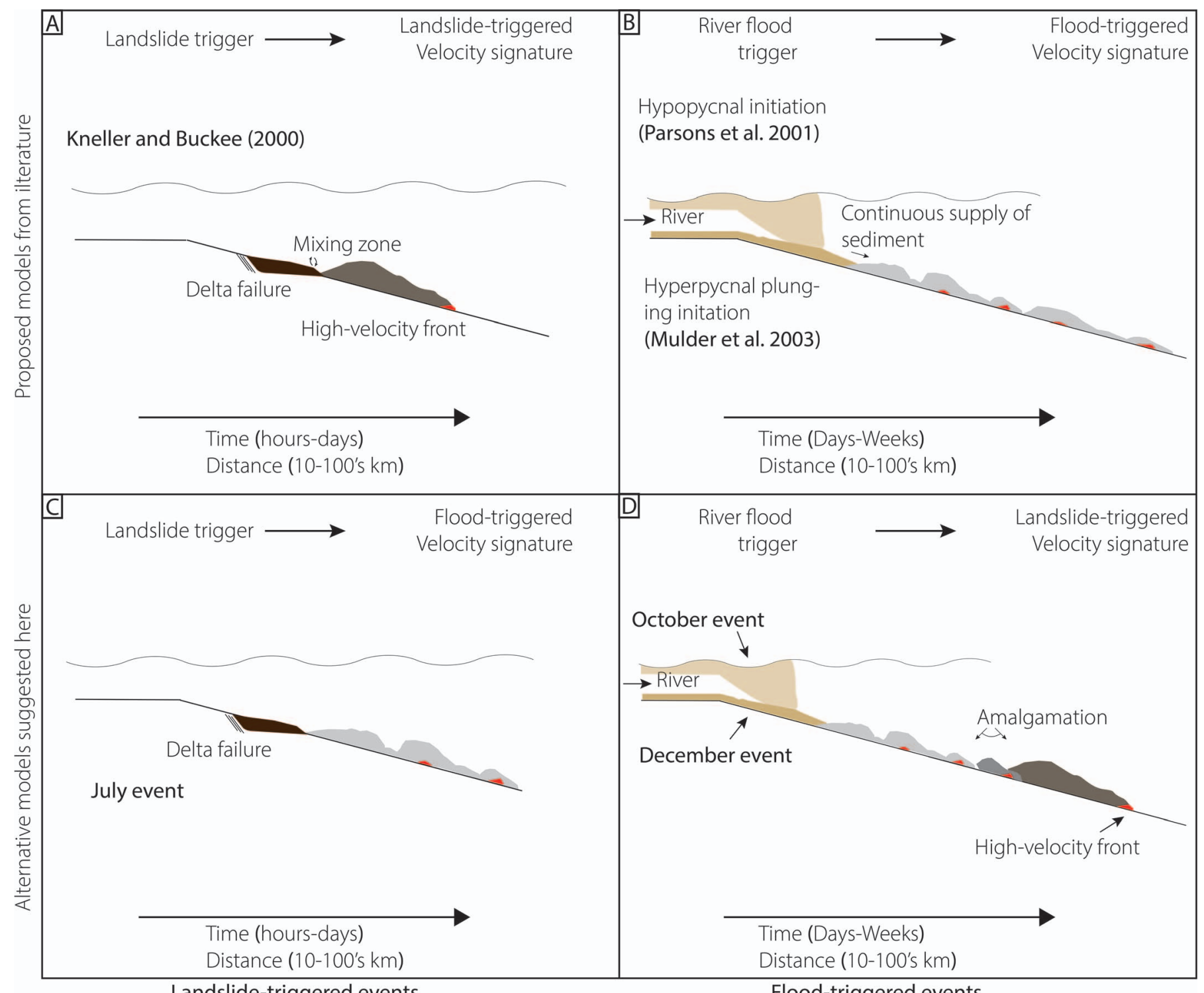

Landslide-triggered events

Flood-triggered events

FIG. 5.- Summary figure of how different triggers are linked to subsequent flow structures. A, B) The classic mechanisms pre-existing in literature, showing how specific triggers lead to unique velocity signatures. C, D) Crossover mechanisms discussed in this study. Here, specific triggers do not lead to their expected velocity signatures.

Finally, it has been suggested that peaks in earthquake shaking patterns (seismograms) can also produce multi-pulsed turbidity currents (Howarth et al. 2021), and that turbidites with multiple pulses may be diagnostic of earthquake triggering (Goldfinger et al. 2003). This study emphasizes that river floods can also produce multi-pulsed turbidity currents, and presumably multi-pulsed turbidites, and that amalgamation of initial pulses can occur over distances of $<16 \mathrm{~km}$. Both of these points may complicate the discrimination of earthquake and flood-triggered turbidity currents (Talling 2021).

\section{CONCLUSIONS}

Turbidity currents without a flood trigger can resemble flood-triggered turbidity currents (Fig. 5), potentially due to a seafloor failure followed by sustained breaching. In addition, flood-triggered turbidity currents can look like landslide-triggered turbidity currents, as erosion and amalgamation in turbidity currents lead to self-organization of the flow within tens of kilometers. Lastly, similar river flood discharges do not consistently lead to similar turbidity currents. Thus, reconstructing paleo-floods on the basis of the rock record might prove substantially more complicated than previously assumed.

\section{ACKNOWLEDGMENTS}

We thank the crew members of the Solveig III cruise, as well as all technicians and the scientific team involved in the efforts. CJH is funded by the European Union's Horizon 2020 research and innovation program under the Marie Skłodowska-Curie grant agreement No 721403-ITN SLATE. MJBC was supported by a Royal Society Research Fellowship (DHF/R1/180166).

\section{REFERENCES}

Azpiroz-Zabala, M., Cartigny, M.J.B., Talling, P.J., Parsons, D.R., Sumner, E.J., Clare, M.A., Simmons, S.M., Cooper, C., And Pope, E.L., 2017, Newly recognized turbidity current structure can explain prolonged flushing of submarine canyons: Science Advances, v. 3, no. e1700200. 
Bailey, L.P., Clare, M.A., Rosenberger, K.J., Cartigny, M.J., Talling, P.J., Paull, C.K., Gwiazda, R., Parsons, D.R., Simmons, S.M., Xu, J., Haigh, I.D., Maier, K.L., McGann, M., Lundsten, E., And Monterey CCE Team, 2021, Preconditioning by sediment accumulation can produce powerful turbidity currents without major external triggers: Earth and Planetary Science Letters, v. 562, no.116845.

Blandin, J., 2010, SOLVEIG III cruise, L'Europe R/V.

Cantero, M.I., Cantelli, A., Pirmez, C., Balachandar, S., Mohrig, D., Hickson, T.A., Yeh, T., NARuse, H., AND Parker, G., 2012, Emplacement of massive turbidites linked to extinction of turbulence in turbidity currents: Nature Geoscience, v. 5, p. 42-45.

Eggenhuisen, J.T., Cartigny, M.J.B., And de Leeuw, J., 2017, Physical theory for near-bed turbulent particle suspension capacity: Earth Surface Dynamics, v. 5, p. 269-281.

Eggenhuisen, J.T., Tilston, M.C., Leeuw, J., Pohl, F., and Cartigny, M.J.B., 2020, Turbulent diffusion modelling of sediment in turbidity currents: an experimental validation of the Rouse approach: The Depositional Record, v. 6, p. 203-216.

FENG, Z.-Z., 2019, Words of the Editor-in-Chief: Some ideas about the comments and discussions of hyperpycnal flows and hyperpycnites: Journal of Palaeogeography, v. 8, p. 25 .

Galy, V., France-Lanord, C., Beyssac, O., Faure, P., Kudrass, H., and Palhol, F., 2007, Efficient organic carbon burial in the Bengal fan sustained by the Himalayan erosional system: Nature, v. 450 , p. $407-410$.

Gavey, R., Carter, L., Liu, J.T., Talling, P.J., Hsu, R., Pope, E., and Evans, G., 2017, Frequent sediment density flows during 2006 to 2015, triggered by competing seismic and weather events: observations from subsea cable breaks off southern Taiwan: Marine Geology, v. 384, p. 147-158.

Goldfinger, C., Nelson, C.H., Johnson, J.E., and Shipboard Scientific Party, 2003, Holocene earthquake records from the Cascadia subduction zone and northern San Andreas fault based on precise dating of offshore turbidites: Annual Review of Earth and Planetary Sciences, v. 31, p. 555-577.

Hage, S., Cartigny, M.J.B., Sumner, E.J., Clare, M.A., Hughes Clarke, J.E., Talling, P.J., Lintern, D.G., Simmons, S.M., Silva Jacinto, R., Vellinga, A.J., Allin, J.R., AzPirozZabala, M., Gales, J.A., Hizzett, J.L., Hunt, J.E., Mozzato, A., Parsons, D.R., Pope, E.L., Stacey, C.D., Symons, W.O., Vardy, M.E., and Watts, C., 2019, Direct monitoring reveals initiation of turbidity currents from extremely dilute river plumes: Geophysical Research Letters, v. 46, p. 11.310-11.320.

Heerema, C.J., Talling, P.J., Cartigny, M.J., Paull, C.K., Bailey, L., Simmons, S.M., Parsons, D.R., Clare, M.A., Gwiazda, R., Lundsten, E., Anderson, K., Maier, K.L., Xu, J.P., Sumner, E.J., Rosenberger, K., Gales, J., McGann, M., Carter, L., and Pope, E., 2020, What determines the downstream evolution of turbidity currents? Earth and Planetary Science Letters, v. 532, no. 116023.

Ho, V.L., Dorrell, R.M., Keevil, G.M., Burns, A.D., and McCaffrey, W.D., 2018, Pulse propagation in turbidity currents: Sedimentology, v. 65, p. 620-637.

Howarth, J.D., Orpin, A.R., Kaneko, Y., Strachan, L.J., Nodder, S.D., Mountjoy, J.J., Barnes, P.M., Bostock, H.C., Holden, C., Jones, K., and CaĞatay, M.N., 2021, Calibrating the marine turbidite palaeoseismometer using the 2016 Kaikōura earthquake: Nature Geoscience, v. 14, p. 161-167.

Hughes Clarke, J.E., 2016, First wide-angle view of channelized turbidity currents links migrating cyclic steps to flow characteristics: Nature Communications, v. 7, no. 11896

Hughes Clarke, J.E.H., Marques, C.R.V., and Pratomo, D., 2014, Imaging active masswasting and sediment flows on a fjord delta, Squamish, British Columbia, in Krastel, S., Behrmann, J.-H., Völker, D., Stipp, M., Berndt, C., Urgeles, R., Chaytor, J., Huhn, K., Strasser, M., and Harbitz, C.B., eds., Submarine Mass Movements and Thei Consequences: Cham, Springer International Publishing, Advances in Natural and Technological Hazards Research, v. 37, p. 249-260.

Khripounoff, A., Vangriesheim, A., Crassous, P., And Etoubleau, J., 2009, High frequency of sediment gravity flow events in the Var submarine canyon (Mediterranean Sea) Marine Geology, v. 263, p. 1-6.

Khripounoff, A., Crassous, P., Lo Bue, N., Dennielou, B., and Silva Jacinto, R., 2012 Different types of sediment gravity flows detected in the Var submarine canyon (northwestern Mediterranean Sea): Progress in Oceanography, v. 106, p. 138-153.

Kirwan, A.D., Jr., Doyle, L.J., Bowles, W.D., And Brooks, G.R., 1986, Time-dependent hydrodynamic models of turbidity currents analyzed with data from the Grand Banks and Orleansville events: Journal of Sedimentary Petrology, v. 56, p. 379-386.

KNeller, B.C., AND BRANNEY, M.J., 1995, Sustained high-density turbidity currents and the deposition of thick massive sands: Sedimentology, v. 42, p. 607-616.

Kneller, B.C., AND Buckee, C., 2000, The structure and fluid mechanics of turbidity currents: a review of some recent studies and their geological implications: structure of turbidity currents: Sedimentology, v. 47, p. 62-94.

Kneller, B.C., And MCCAfFrey, W.D., 2003, The interpretation of vertical sequences in turbidite beds: the influence of longitudinal flow structure: Journal of Sedimentary Research, v. 73, p. 706-713.

Lintern, D.G., Hill, P.R., and Stacey, C., 2016, Powerful unconfined turbidity current captured by cabled observatory on the Fraser River delta slope, British Columbia, Canada: Sedimentology, v. 63, p. 1041-1064.

Liu, J.T., WAng, Y.-H., Yang, R.J., Hsu, R.T., KaO, S.-J., Lin, H.-L., and KuO, F.H., 2012, Cyclone-induced hyperpycnal turbidity currents in a submarine canyon: Journal of Geophysical Research, Oceans, v. 117, no. C04033.

LowE, D.R., 1982, Sediment gravity flows, II: depositional models with special reference to the deposits of high-density turbidity currents: Journal of Sedimentary Petrology, v. 52, p. 279-297.
Mas, V., Mulder, T., Dennielou, B., Schmidt, S., Khripounoff, A., and Savoye, B., 2010, Multiscale spatio-temporal variability of sedimentary deposits in the Var turbidite system (North-Western Mediterranean Sea): Marine Geology, v. 275, p. 37-52.

Mastbergen, D.R., and Van Den Berg, J.H., 2003, Breaching in fine sands and the generation of sustained turbidity currents in submarine canyons: breaching in submarine canyons: Sedimentology, v. 50, p. 625-637.

Mulder, T., And Alexander, J., 2001, The physical character of subaqueous sedimentary density flows and their deposits: Sedimentology, v. 48, p. 269-299.

Mulder, T., AND SyviTSKI, J.P.M., 1995, Turbidity currents generated at river mouths during exceptional discharges to the world oceans: The Journal of Geology, v. 103, p. 285-299.

Mulder, T., Savoye, B., And Syvitski, J.P.M., 1997, Numerical modelling of a mid-sized gravity flow: the 1979 Nice turbidity current (dynamics, processes, sediment budget and seafloor impact): Sedimentology, v. 44, p. 305-326.

Mulder, T., Savoye, B., Piper, D.J.W., And Syvitski, J.P.M., 1998, The Var submarine sedimentary system: understanding Holocene sediment delivery processes and their importance to the geological record, in Stoker, M.S., Evans, D., and Cramp, A. eds., Geological Processes on Continental Margins: Sedimentation, Mass-Wasting and Stability: Geological Society of London, Special Publication 129, p. 145-166.

Mulder, T., Migeon, S., Savoye, B., and Jouanneau, J.-M., 2001, Twentieth century floods recorded in the deep Mediterranean sediments: Geology, v. 29, p. 1011-1014.

Mulder, T., Syvitski, J.P.M., Migeon, S., Faugères, J.-C., and Savoye, B., 2003, Marine hyperpycnal flows: initiation, behavior and related deposits. A review: Marine and Petroleum Geology, v. 20, p. 861-882.

NAKAJima, T., 2006, Hyperpycnites deposited $700 \mathrm{~km}$ away from river mouths in the Central Japan Sea: Journal of Sedimentary Research, v. 76, p. 60-73.

Normark, W.R., AND PIPER, D.J.W., 1991, Initiation processes and flow evolution of turbidity currents: implications for the depositional record, in Osborne, R.H., ed., From Shoreline to Abyss: SEPM, Special Publication 46, p. 207-230.

Parker, G., Fukushima, Y., and Pantin, H.M., 1986, Self-accelerating turbidity currents: Journal of Fluid Mechanics, v. 171, p. 145-181.

Parsons, J.D., Bush, J.W.M., AND Syvitski, J.P.M., 2001, Hyperpycnal plume formation from riverine outflows with small sediment concentrations: Sedimentology, v. 48, p. 465478 .

PiPer, D.J.W., AND SAVoye, B., 1993, Processes of late Quaternary turbidity current flow and deposition on the Var deep-sea fan, north-west Mediterranean Sea: Sedimentology, v. 40, p. 557-582.

Plink-BjöRKlund, P., And Steel, R.J., 2004, Initiation of turbidity currents: outcrop evidence for Eocene hyperpycnal flow turbidites: Sedimentary Geology, v. 165, p. 29-52. Sequeiros, O.E., Naruse, H., Endo, N., Garcia, M.H., and Parker, G., 2009, Experimental study on self-accelerating turbidity currents: Journal of Geophysical Research, v. 114, no. C05025.

Shanmugam, G., 2018, The hyperpycnite problem: Journal of Palaeogeography, v. 7, p. 6. Silva JACINTO, R., 2008, SOLVEIG I cruise, Europe R/V.

Simmons, S.M., Azpiroz-Zabala, M., Cartigny, M.J.B., Clare, M.A., Cooper, C., Parsons, D.R., Pope, E.L., Sumner, E.J., And Talling, P.J., 2020, Novel acoustic method provides first detailed measurements of sediment concentration structure within submarine turbidity currents: Journal of Geophysical Research: Oceans, v. 125, no. e2019JC015904.

Stacey, M.W., and Bowen, A.J., 1988, The vertical structure of turbidity currents and a necessary condition for self-maintenance: Journal of Geophysical Research, v. 93, p. 3543-3553.

St-Onge, G., Mulder, T., Piper, D.J.W., Hillaire-Marcel, C., and Stoner, J.S., 2004, Earthquake and flood-induced turbidites in the Saguenay Fjord (Québec): a Holocene paleoseismicity record: Quaternary Science Reviews, v. 23, p. 283-294.

TALLING, P.J., 2014, On the triggers, resulting flow types and frequencies of subaqueous sediment density flows in different settings: Marine Geology, v. 352, p. 155-182.

TALLING, P.J., 2021, Fidelity of turbidites as earthquake records: Nature Geoscience, v. 14, p. 113-116.

Thorne, P.D., And Hanes, D.M., 2002, A review of acoustic measurement of small-scale sediment processes: Continental Shelf Research, v. 22, p. 603-632.

van Loon, A.J., Hüneke, H., ANd Mulder, T., 2019, The hyperpycnite problem: comment: Journal of Palaeogeography, v. 8, p. 24.

Zavala, C., 2019, The new knowledge is written on sedimentary rocks: a comment on Shanmugam's paper "the hyperpycnite problem": Journal of Palaeogeography, v. 8, p. 23.

Zavala, C., And Pan, S.X., 2018, Hyperpycnal flows and hyperpycnites: origin and distinctive characteristics: Lithologic Reservoirs, v. 30, p. 1-27.

Zavala, C., Ponce, J.J., Arcuri, M., Drittanti, D., Freije, H., and Asensio, M., 2006, Ancient lacustrine hyperpycnites: a depositional model from a case study in the Rayoso Formation (Cretaceous) of west-central Argentina: Journal of Sedimentary Research, v. 76, p. 41-59.

Zavala, C., Arcuri, M., Di Meglio, M., Gamero, H., and Contreras, C., 2011, A genetic facies tract for the analysis of sustained hyperpycnal flow deposits: American Association of Petroleum Geologists, Studies in Geology, v. 61, p. 31-51.

Received 27 October 2020; accepted 16 September 2021. 